\title{
PENGARUH PEMANFAATAN TEKNOLOGI INFORMASI TERHADAP MINAT BELAJAR SISWA
}

\author{
Novita Ahmad ${ }^{1)}$,Rosman Ilato ${ }^{2)}$, Boby R.Payu ${ }^{2)}$ \\ SMA Negeri 1 Ampana Kota, Sulawesi Tengah ${ }^{1}$ \\ Email: novitahahmad@gmail.com ${ }^{1}$
}

\begin{abstract}
ABSTRAK
Penelitian ini bertujuan untuk mengetahui pengaruh pemanfaatan teknologi informasi terhadap minat belajar siswa kelas X jurusan Ilmu Pengetahuan Sosial di SMA Negeri 1 Kota Gorontalo.Pendekatan yang digunakan dalam penelitian ini adalah pendekatan kuantitatif dengan metode ex post facto.Populasi pada penelitian ini adalah 166 orang siswa.Sedangkan sampel dalam penelitian ini berjumlah 62 responden. Data yang digunakan dalam penelitian yaitu kuesioner/angket sebanyak 30 pertanyaan yang terdistribusi 15 pertanyaan indikator Teknologi Informasi dan 15 pertanyaan indikator Minat Belajar Siswa. Adapun tehnik analisis data yang digunakan yaitu uji normalitas data dan analisis regresi.Penelitian ini menyimpulkan bahwa terdapat pengaruh yang signifikan pemanfaatan teknologi informasi terhadap minat belajar siswa kelas X IPS di SMA Negeri 1 Kota Gorontalo. Hal ini ditunjukan pengaruh pemanfaatan teknologi informasi terhadap minat belajar siswa mencapai $36 \%$ dan sisanya $64 \%$ minat belajar siswa dipengaruhi oleh variabel lain.
\end{abstract}

Kata Kunci: Teknologi Informasi, Minat Belajar

\begin{abstract}
This study aims to determine the effect of the use of information technology on student interest in class X majoring in Social Sciences at SMA Negeri 1 Gorontalo City. The approach used in this research is a quantitative approach with the ex post facto method. The population in this study was 166 students. While the sample in this study amounted to 62 respondents. The data used in the study were questionnaire / questionnaire as many as 30 questions distributed 15 questions Technology Information indicator questions and 15 questions Student Interest Interest indicators. The data analysis technique used is data normality test and regression analysis. This study concludes that there is a significant influence of the use of information technology on the learning interest of students of class X IPS in SMA Negeri 1 Gorontalo City. This is indicated by the influence of the use of information technology on student learning interest reaching $36 \%$ and the remaining $64 \%$ student learning interest is influenced by other variables
\end{abstract}

Keywords: Information Technology, Learning Interest 


\section{PENDAHULUAN}

Belajar mengajar merupakan kegiatan utama yang ada di sekolah. Harapan yang tidak pernah sirna dari seorang guru adalah siswa-siswanya berhasil dalam pembelajaran. Keberhasilan tersebut selalu dibarengi dengan usaha-usaha baik dari guru maupun dari siswa sendiri. Seorang guru mengupayakan berbagai metode-metode dalam menyampaikan ilmu pengetahuan. Tujuan adanya berbagai macam metode yang digunakan adalah agar siswa tidak merasa jenuh dan memiliki minat dalam proses belajarnya.(Benar, 2019). Selain itu, guru juga selalu memberikan berbagai motivasi guna membangkitkan semangat belajar siswa.Kegiatan belajar yang dilakukan baik di sekolah maupun di rumah harus berdasarkan dari keinginan yang timbul dari dalam dirinya. Jika seorang siswa telah berkeinginan dari dalam diri untuk belajar maka, siswa akan memiliki rasa ketertarikan untuk belajar.(Sunadi, 2010) Ketertarikan yang dimaksud adalah minat. Siswa yang memiliki minat terhadap suatu hal yaitu belajar maka siswa akan berusaha semaksimal mungkin untuk mencapai tujuan dari kegiatan belajarnya. Minat adalah suatu rasa lebih suka dan rasa ketertarikan pada suatu hal atau aktivitas, tanpa ada yang menyuruh. Suatu minat dapat diekspresikan melalui suatu pernyataan yang menunjukan bahwa siswa lebih menyukai suatu hal dari pada hal lainnya.(Purwanti, 2012)

Minat belajar siswa merupakan hal yang sangat perlu diperhatikan dalam proses pembelajaran. Karena tanpa adanya minat belajar dari siswa proses pembelajaran tidak akan dapat berlangsung secara maksimal. Minat merupakan modal awal untuk mencapai keberhasilan dalam proses pembelajaran. Dengan adanya minat, maka muncul motivasi dari siswa untuk mengikuti proses pembelajaran dengan serius dari awal sampai akhir sehingga tercapai hasil pembelajaran yang baik. Menurut Slameto (2003) siswa yang berminat dalam belajar adalah sebagai berikut: 1) Memiliki kecenderungan yang tetap untuk memperhatikan dan mengenang sesuatu yang dipelajari secara terus menerus; 2) ada rasa suka dan senang terhadap sesuatu yang diminatinya; 3) memperoleh sesuatu kebanggaan dan kepuasan pada suatu yang diminati; 4) lebih menyukai hal yang lebih menjadi minatnya dari pada hal yang lainnya; dan 5) dimanifestasikan melalui partisipasi pada aktivitas dan kegiatan. Dari pendapat di atas dapat disimpulkan bahwa ciri-ciri minat belajar adalah memiliki kecenderungan yang tetap untuk memperhatikan dan mengenang sesuatu secara terus menerus, memperoleh kebanggaan dan kepuasan terhadap hal yang diminati, berpartisipasi pada pembelajaran, dan minat belajar dipengaruhi oleh budaya. Ketika siswa ada minat dalam belajar maka siswa akan senantiasa aktif berpartisipasi dalam pembelajaran dan akan memberikan prestasi yang baik dalam pencapaian prestasi belajar. Minat berkaitan erat dengan tujuan. Seseorang yang memiliki minat yang tinggi akan sungguh-sungguh berusaha mencapai tujuan yang dikehendakinya. Minat siswa dalam pembelajaran menjadi kekuatan yang akan mendorong siswa untuk belajar. Minat belajar yang dimiliki siswa berbeda satu dengan yang lainnya(Flora Siagian, 2015).

Bagi remaja yang menduduki sekolah menengah atas minat belajar menjadi faktor yang perlu diperhatikan secara khusus. Terlebih lagi banyak hal-hal yang dirasa lebih menarik dari pada kegiatan belajar, banyak faktor yang mempengaruhi minat belajar siswa. Seharusnya siswa yang memiliki minat belajar, akan menunjukan rasa 
bersemangat saat mengikuti pembelajaran dengan mendengarkan penjelasan guru dan mencatat materi yang diberikan, fokus terhadap pembelajaran dan tidak memikirkan hal-hal yang tidak berkaitan dengan pembelajaran, memiliki perasaan senang terhadap pelajaran tertentu sehingga tidak ada rasa bosan dan terpaksa untuk belajar, selalu menunjukan antusias yang tinggi seperti pada saat diskusi selalu aktif bertanya dan menjawab pertanyaan dari guru serta tidak menunda tugas yang diberikan oleh guru. (Slameto, 2010). Minat belajar siswa juga dapat dipengaruhi oleh penggunaan teknologi informasi. Penggunaan teknologi informasi di sekolah mempunyai manfaat yang sangat banyak dalam proses pembelajaran, karena dengan adanya teknologi informasi, siswa dapat melihat informasi-informasi terbaru maupun fenomena yang terjadi pada saat ini yang kemudian dihubungkan dengan materi pelajaran, siswa juga dapat menggunakan teknologi informasi sebagai media dalam menyampaikan informasi sehingga siswa menjadi termotivasi untuk belajar dan proses belajar mengajar tidak monoton. Penggunaan teknologi informasi yang dimaksud dalam penelitian ini adalah gadget. Perkembangan teknologi informasi khususnya gadget menimbulkan dampak positif bagi para siswa dalam meningkatkan minat belajar siswa. Dampak positif dari penggunaan gadget yaitu mempermudah dalam pencarian informasi dan komunikasi serta menjadikan siswa tidak gagap teknologi.

Pemanfaatan gadget dalam kegiatan pembelajaran memberikan pengaruh terhadap pencapaian proses pembelajaran yang memberikan rangsangan untuk dapat meningkatkan semangat serta minat bagi siswa dalam memahami pelajaran Berdasarkan observasi yang peneliti lakukan, yakni di SMA Negeri 1 Kota Gorontalo. Peneliti menemukan informasi yang sama mengenai pemanfaatan teknologi informasi. Hasil observasi menunjukan bahwa banyak siswa yang menggunakan gadget untuk memperoleh bahanbahan yang menunjang pembelajaran. Misalnya mencari tambahan materi, mengerjakan tugas sekolah, serta mengakses informasi yang mereka butuhkan. Namun hasil observasi juga menunjukan bahwa masih ada siswa Ketika berada di dalam kelas siswa selalu menggunakan gadget untuk bermain game, chating, serta facebook tanpa memperhatikan penjelasan dari guru.Ketika guru menegur, siswa hanya meletakkan gadgetnya sebentar di dalam laci meja lalu kemudian bermain gadget lagi. Penggunaan gadget saat jam pembelajaran tidak baik untuk siswa, karena dapat mengganggu ketika guru sedang menerangkan materi yang seharusnya diperhatikan oleh siswa. Siswa menjadi tidak peka terhadap pembelajaran, siswa hanya lebih fokus di gadget dan tidak memperhatikan pembelajaran yang berlangsung. Hal ini berdampak pada minat belajar siswa yang masih rendah terlihat dari para siswa yang sering keluar masuk kelas saat pembelajaran berlangsung, berbicara dengan teman sebelah tanpa memperhatikan penjelasan guru. Pada saat diskusi berlangsung, siswa mengobrol dengan kelompoknya di luar tema diskusi, Ketika guru menanyakan hasil diskusi pada siswa, siswa justru meminta perpanjangan waktu karena belum selesai mengerjakan tugas diskusi. Pada saat pembahasan diskusi, guru sering kali meminta siswa untuk mengemukakan pendapatnya namun hanya satu atau dua saja yang berpendapat, sehingga proses pembelajaran tidak berlangsung dengan baik.

Minat belajar adalah suatu penerimaan akan suatu hubungan antara diri sendiri dengan sesuatu diluar diri. Seseorang memiliki minat terhadap subjek tertentu 
cenderung untuk memberikan perhatian yang lebih besar terhadap subjek tertentu (Djamarah Syaiful, 2008). Minat belajar dapat membentuk sikap akademik tertentu yang bersifat sangat pribadi pada setiap siswa. Oleh karena itu minat belajar harus ditumbuhkan sendiri oleh masing-masing siswa. Pihak lainnya hanya memperkuat dan menumbuhkan minat atau untuk memelihara minat yang telah dimiliki seseorang (Leokmono, 1994). Minat belajar juga merupakan tenaga penggerak yang dipercaya ampuh dalam proses belajar. Oleh sebab itu, sudah semestinya pengajaran memberi peluang yang lebih besar bagi perkembangan minat seorang peserta didik.Minat erat sekali hubunganya dengan perasaan suka dan tidak suka, tertarik atau tidak tertarik.

Menurut Slameto (2010) beberapa indikator minat belajar yaitu: perasaan senang, ketertarikan, penerimaan, dan keterlibatan siswa. Dari beberapa definisi yang dikemukakan mengenai indikator minat belajar tersebut diatas, dalam penelitian ini menggunakan indikator minat, yaitu: perasaan senang, keterlibatan siswa, ketertarikan, perhatian siswa.

Dalam pengertian sederhana, minat adalah keinginan terhadap sesuatu tanpa ada paksaan. Dalam minat belajar seorang siswa memiliki faktor-faktor yang mempengaruhi minat belajar yang berbeda-beda.(Mulusi \& Wardiyanto, 2013). menurut Syah (2003) membedakannya menjadi tiga macam, yaitu: a) faktor internal adalah faktor dari dalam diri siswa yang meliputi dua aspek, yakni: aspek fisiologis kondisi jasmani dan tegangan otot (tonus) yang menandai tingkat kebugaran tubuh siswa, hal ini dapat mempengaruhi semangat dan intensitas siswa dalam pembelajaran; aspek psikologis aspek psikologis merupakan aspek dari dalam diri siswa yang terdiri dari, intelegensi, bakat siswa, sikap siswa, minat siswa, motivasi siswa. b) faktor eksternal siswa faktor eksternal terdiri dari dua macam, yaitu faktor lingkungan social dan faktor lingkungan nonsosial.

Martin (1999) dalam Rakhmansyah dan Susilo (2014) menyatakan bahwa teknologi informasi tidak hanya terbatas pada teknologi computer (perangkat keras dan perangkat lunak) yang digunakan untuk memproses dan menyimpan informasi, melainkan juga mencakup teknologi komunikasi untuk mengirimkan informasi. Menurut Lucas (2000), teknologi informasi adalah segala bentuk teknologi yang diterapkan untuk memproses dan mengirimkan informasi dalam bentuk elektronis. Teknologi informasi adalah seperangkat alat yang membantu dalam bekerja dengan informasi dan melakukan tugas-tugas yang berhubungan dengan pemrosesan informasi. Lucas (2000) menjelaskan Teknologi informasi adalah segala bentuk teknologi yang diterapkan untuk memproses dan mengirimkan informasi dalam bentuk elektronis. Dengan melihat beberapa pengertian di atas dapat disimpulkan pengertian pemanfaatan teknologi informasi adalah suatu bentuk teknologi yang memudahkan pekerjaan manusia dalam memproses, mendapatkan, menyusun dan menyajikan informasi.

Pemanfaatan dari penggunaan teknologi informasi dapat diketahui dalam memutuskan penerimaan teknologi informasi dengan satu kepercayaan bahwa pengguna teknologi informasi tersebut dapat memberikan konstribusi positif bagi penggunanya.) Pemanfaatan teknologi informasi dibagi menjadi lima dimensi yaitu: 1) bermanfaat (usefull) Perkembangan teknologi informasi sangat berdampak pada kehidupan manusia untuk kelangsungan serta kenyamanan hidup manusia dengan 
memberikan berbagai manfaat dalam meningkatkan kualitas hidup yang lebih baik; 2) pekerjaan menjadi lebih mudah (makes job easier) kehadiran teknologi informasi memberikan kemudahan dalam pengolahan, penyediaan informasi secara mudah dan cepat sehingga dapat mendukung proses, kegiatan, pekerjaan, serta pengambilan keputusan secara efektif dan efisien; 3) menambah produktifitas (increas productivity) dengan adanya teknologi informasi, manusia menjadi lebih produktif dalam menciptakan atau Menghasilkan sesuatu yang menguntungkanbagi kehidupan sekarang dan dimasa yang akan datang; 4) mempertinggi efektifitas (enchance effectiveness) efektifitas merupakan kemampuan untuk memilih tujuan yang tepat untuk pencapaian tujuan yang telah ditetapkan serta sebagai suatu ukuran yang memberikan gambaran tentang pencapaian suatu target; dan 5) meningkatkan kinerja (improve the performance) pemanfaatan teknologi informasi pada dasarnya sebagai sarana untuk meningkatkan efektivitas kerja, menghemat waktu, tenaga, pikiran, serta mempercepat arus informasi.(Hariyani, 2014)

Dunia pendidikan tidak terlepas dari teknologi informasi. Dunia pendidikan berkaitan erat dengan informasi dan pengetahuan.Oleh karena itu, akses yang mudah kepada informasi dan pengetahuan menjadi sangat penting. Teknologi informasi juga dapat melahirkan fiturfitur baru dalam dunia pendidikan.Seperti pada sistem pengajaran berbasis multimedia (teknologi yang melibatkan teks, gambar, suara, dan video) dapat menyajikan materi pelajaran yang lebih menarik, tidak monoton, dan memudahkan penyampaian. Pemanfaatan teknologi informasi yang dimaksud dalam penelitian ini penggunaan atau pemanfaatan gadget untuk pembelajaran.

Menurut Widyawati dan Sugiman (2014) gedget merupakan barang canggih yang diciptakan dengan berbagai aplikasi yang daaat menyajikan berbagai media berita dijring media sosial, hobi bahkan hiburan.Gedget adalah media yang dipakai sebagai alat komunukasi moderen dan semakin mempermudah kegiatan komunikasi manusia. Pendapat diatas dapat disimpulkan bahwa gadget merupakan sebuah teknologi berupa barang canggih yang diciptakan dengan berbagai fungsi dan kegunaannya.

\section{METODE PENELITIAN}

Metode penelitian yang digunakan pada penelitian ini adalah metode ex-post facto, yaitu metode yang digunakan pada kegiatan atau kejadian yang sudah terjadi yaitu melihat pengaruh pemanfaatan teknologi informasi terhadap minat belajar siswa.Penelitian ini menggunakan pendekatan kuantitatif. Pendekatan penelitian kuantitatif digunakan untuk meneliti pada populasiatau sampel tertentu. Tehnik pengambian sampel pada umumnya dilakukan secara random, pengumpulan data bersifat kuantitatif statistik dengan tujuan untuk menguji hipotesis yang telah ditetapkan (Sugiono, 2015). Populasi adalah wilayah generelisasi yang terdiri atas objek/subjek yang mempunyai kuantitas, dan karakteristik tertentu yang ditetapkan oleh peneliti untuk dipelajari dan menarik kesimpulan (Sugiyono, 2009). Berdasarkan pengertian tersebut maka yang menjadi populasi dalam penelitian ini adalah seluruh siswa kelas X IPS di SMA Negeri 1 Kota Gorontalo yang berjumlakan 166 siswa. Pengambilan sampel menurut Arikunto (2002), apabila subjek kurang dari 100, maka lebih baik diambil semua sehingga penelitiannya merupakan populasi. Jika subjek lebih 
besar dari 100, maka besar sampel dapat diambil antara $10-15 \%$ atau $20-25 \%$. Namun dalam penelitian ini, peneliti mengambil besarnya sampel dengan menggunakan rumus Natoatmodjo (2002). Maka yang menjadi sampel dalam penelitian ini adalah 62 orang. Teknik pengumpulan data yang digunakan adalah angket, observasi, dan dokumentasi. Sedangkan teknik pengujian menggunakan uji validitas, reliabilitas, normalitas dan regresi. Teknik analisis data di gunakan dalam penelitian ini adalah regresi linier sederhana. Persamaan umum regresi linier sederhana adalah:

$$
\mathrm{Y}=\alpha+\beta_{1} \mathrm{X}_{1}+\mathrm{e}
$$

Keterangan:

$\mathrm{Y}=$ Minat belajar siswa

$\mathrm{X}_{1}=$ Teknologi informasi

$\beta=$ koefisien regresi

$\alpha=$ Konstanta

$\mathrm{e}=$ eror term

\section{HASIL DAN PEMBAHASAN}

a. Hasil Ujian Normalitas

Sebelum melakukan analisis data dengan menggunakan regresi, terlebih dahulu dilakukan pengecekan persyaratan analisis Untuk keperluan ini, akan dilakukan pengujian normalitas data dengan menggunakan uji kolmogorv-smirnov (KS) dengan prosedur sebagai berikut: 1) menentukan hipotesis, 2) menentukan tingkat signifikansi, 3) menentukan statistik uji, dan 4) menentukan kriteria uji .Hasil pengujian normalitas data dengan menggunakan SPSS adalah sebagai berikut:

Tabel 1. Hasil Uji kolmogorv-smirnov

\begin{tabular}{l|r|c}
\hline \multicolumn{2}{c|}{ One-Sample Kolmogorov-Smirnov Test } & Keterangan \\
\hline $\mathrm{N}$ & 62 & \\
Std. Deviation & 7.80603 & Normal \\
Asymp. Sig. (2-tailed) & 0.855 & \\
\hline
\end{tabular}

Sumber : Hasil olah data

Hasil analisis diatas menunjukkan nilai rata-rata minat belajar dari 62 orang siswa yang diamati adalah sebesar 50,98 dengan nilai standar deviasi sebesar 7,81. Sedangkan hasil pengujian normalitas datadengan Kolmogorov Smirnov menunjukkan nilai signifikansi untuk pengujian normalitas data minat belajar untuk 62 orang siswa yang diamati adalah sebesar 0,855. Jika dibandingkan dengan nilai alpha yangdigunakan $(0,05)$ maka nilai signifikansi yang diperoleh ini masih lebih besar sehingga Ho diterima. Dengan demikian dapat disimpulkan bahwa data variabel dependen (minat belajar siswa) telah berdistribusi normal.

b. Hasil Analisis Regresi

Setelah persyaratan normalitas data dipenuhi maka selanjutnya dilakukan analisis regresi antara teknologi informasi dengan minat belajar siswa di Kelas $\mathrm{X}$ Jurusan Ilmu Pengetahuan Sosial (IPS) di SMA Negeri 1 Kota Gorontalo. Teknik 
analisis yang digunakan adalah analisis regresi linear sederhana. Hasil analisis regresi dengan menggunakan bantuan SPSS adalah sebagai berikut:

Tabel 2. Hasil uji regresi linear sederhana

\begin{tabular}{|c|c|c|c|c|}
\hline \multicolumn{5}{|c|}{ Coefficients $^{\mathrm{a}}$} \\
\hline & & \multicolumn{2}{|c|}{ Unstandardized Coefficients } & Standardized Coefficients \\
\hline \multicolumn{2}{|c|}{ Model } & $\mathrm{B}$ & Std. Error & Beta \\
\hline \multirow[t]{2}{*}{1} & (Constant) & 24.134 & 4.695 & \\
\hline & teknologiinformasi & .557 & .096 & .600 \\
\hline
\end{tabular}

Sumber : Hasil Olah data

Dengan demikian model analisis regresi pengaruh teknologi informasi terhadap minat belajar siswa adalah sebagai berikut:

$$
\mathrm{Y}=24.134+0.557 \mathrm{x}
$$

Berdasarkan hasil analisis diatas dapat ditafsirkan beberapa hal sebagai berikut : 1) Pemanfaatan teknologi informasi berpengaruh positif terhadap minat belajar siswa Kelas X Jurusan Ilmu Pengetahuan Sosial (IPS) Di SMA Negeri 1 Kota Gorontalo. Semakin baik pemanfataan teknologi informasi oleh siswa maka akan mampu meningkatkan minat mereka dalam belajar. 2. Setiap peningkatan pemanfaatan teknologi informasi sebesar satu satuan akan meningkatkan minat belajar siswa sebesar 0,557 satuan.

c. Pengujian Model Regresi Secara Keseluruhan

Setelah diperoleh model persamaan regresi taksiran maka langkah selanjutnya adalah melakukan pengujian signifikansi koefisien regresi secara bersama-sama (testing the overall significance of regression). Pengujian secara simultan dilakukan dengan menggunakan uji F. Langkah-langkah pengujiannya adalah sebagai berikut: 1) penentuan hipotesis Ho seluruh koefisien regresi tidak signifikan (model regresi tidak signfikan) H1: minimal satu koefisien regresi signifikan (model regresi signfikan). Hasil pengujian dengan menggunakan SPSS adalah sebagai berikut:

Tabel 3. Hasil uji F

\begin{tabular}{|c|c|c|c|c|c|c|}
\hline \multicolumn{7}{|c|}{$\mathrm{ANOVA}^{\mathrm{a}}$} \\
\hline Model & & $\begin{array}{c}\text { Sum of } \\
\text { Squares }\end{array}$ & df & Mean Square & $\mathrm{F}$ & Sig. \\
\hline \multirow[t]{3}{*}{1} & Regression & 1336.554 & 1 & 1336.554 & 33.689 & $.000^{\mathrm{b}}$ \\
\hline & Residual & 2380.430 & 60 & 39.674 & & \\
\hline & Total & 3716.984 & 61 & & & \\
\hline
\end{tabular}

Sumber : Hasil olah data

Dari hasil diatas didapat nilai F-hitung sebesar 33,689. Adapun nilai F-tabel pada tingkat signifikansi 5\% dan derajat bebas pembilang (df1) sebesar k (jumlah variabel bebas) $=1$ dan derajat bebas penyebut (df2) sebesar N-k-1 = 62-1-1 = 60 adalah sebesar 
4,001. Jika kedua nilai $\mathrm{F}$ ini dibandingkan, maka nilai F-hitung yang diperoleh jauh lebih besar Ftabel sehingga Ho ditolak.Jika menggunakan nilai signifikansi, dari hasil analisis diatas diperoleh nilai signifikansi sebesar 0,000. Nilai ini sangat kecil jika dibandingkan dengan nilai alpha yang digunakan yakni sebesar 0,05. Dengan demikian dapat disimpulkan bahwa seluruh koefisien regresi dalam model secara bersama-sama berpengaruh terhadap minat belajar siswa.

4. Pengujian Pengaruh Pemanfaatan Teknologi Informasi Terhadap Minat Belajar Siswa

Setelah diketehui bahwa secara model regresi signifikan maka selanjutnya akan dilakukan pengujian lebih lanjut untuk mengetahui secara lebih spesifik pengaruh dari pemanfaatan teknologi informasi terhadap minat belajar siswa. Untuk keperluan ini dilakukan pengujian koefisien regresi secara individual (testing individual regression coefficient). Individual (testing individual regression coefficient). Adapun tahapan pengujian yang akan dilakukan adalah sebagai berikut: 1. Penentuan Hipotesis H0 (tidak terdapat pengaruh dari pemanfaatan teknologi informasi terhadap minat belajar siswa) H1 (terdapat pengaruh dari pemanfaatan teknologi informasi terhadap minat belajar siswa) 2. Penentuan tingkat signifikansi Tingkat kepercayaan yang akan digunakan dalam penelitian ini adalah sebesar 95\% atau dengan kata lain tingkat signfikansinya (alpha) sebesar 5\%

\section{Penentuan Kriteria uji}

Penentuankriteria uji didasarkan pada perbandingan antara nilai thitung yang diperoleh dengan t-tabel.Jika nilai t-hitung lebih besar dari t- tabel maka Ho ditolak.Pengujian juga dapat didasarkan pada perbandingan antara nilai signiifkansi yang diperoleh dengan nilai alpha yang digunakan.Jika nilai signifikansi yang diperoleh lebih besar dari nilai alpha maka Ho diterima. Hasil pengujian dengan menggunakan bantuan SPSS adalah sebagai berikut:

Tabel 4. Hasil uji T

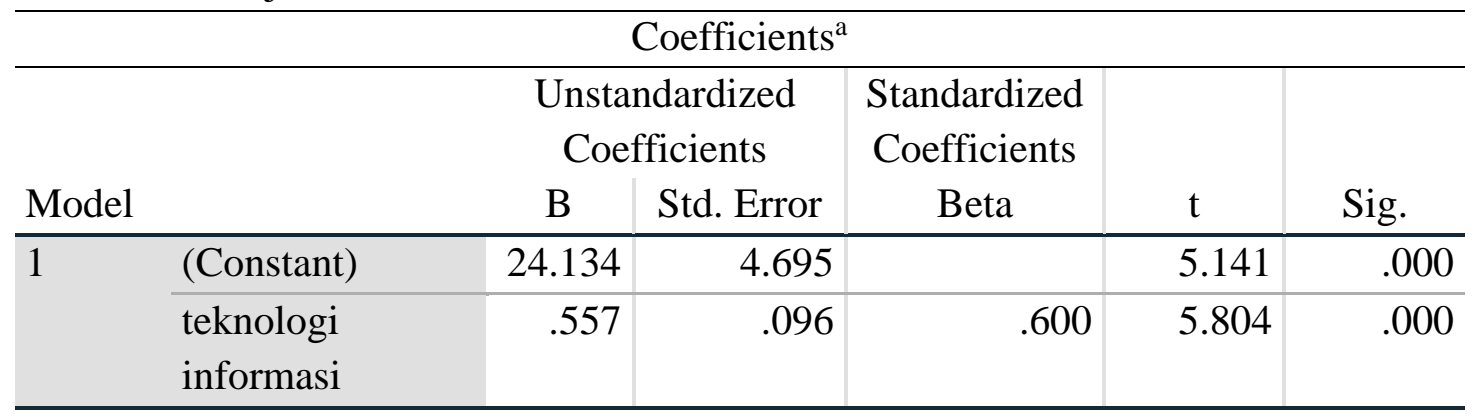

Sumber : Hasil olah data

Dari output diatas dapat dilihat nilai t-tabel yang diperoleh untuk variabel pemanfaatan teknologi informasi adalah sebesar 5,804. Untuk mendapatkan kesimpulan apakah menerima atau menolak Ho, terlebih dahulu harus ditentukan nilai t-tabel yang akan digunakan. Nilai t-tabel ini bergantung pada besarnya df (degree of freedom) serta tingkat signifikansi yang digunakan. Dengan menggunakan tingkat signifikansi sebesar $5 \%$ dan nilai df sebesar $\mathrm{N}-\mathrm{K}-1=62-1-1=60$ diperoleh nilai t-tabel sebesar 2,00. Jika dibandingkan dengan nilai t-hitung yang diperoleh sebesar 5,804 maka nilai t-hitung 
yang diperoleh masih lebih besar dari nilai t-tabel sehingga Ho ditolak.Dengan demikian pada tingkat kepercayaan $95 \%$ dapat disimpulkan bahwa teknologi informasi berpengaruh secara signifikan terhadap minat belajar siswa.E. Penafsiran Koefisien Determinasi Untuk mengetahui besar pengaruh dari seluruh variabel bebas dalam model terhadap kualitas digunakan analisis koeifsien determinasi.Nilai koefisien determinasi mencerminkan besarnya pengaruh perubahan variabel bebas dalam menjalankan perubahan pada variabel tidak bebas secara bersama-sama, dengan tujuan untuk mengukur kebenaran dan kebaikan hubungan antar variable dalam model yang digunakan.Besarnya nilai R2 berkisar antara $0<\mathrm{R} 2<1$.Jika nilai R2 semakin mendekati satu maka model yang diusulkan dikatakan baik karena semakin tinggi variasi variabel dependen yang dapat dijelaskan oleh variabel independen. Nilai koefisien determinasi untuk model regresi antara teknologi informasi dengan minat belajar siswa adalah sebagai berikut:

Tabel 5 Hasil uji determinasi

\begin{tabular}{ll|r|r|r}
\hline \multicolumn{5}{c}{ Model Summary } \\
\hline Model & $\mathrm{R}$ & \multicolumn{1}{c}{ R Square } & Adjusted R Square & $\begin{array}{c}\text { Std. Error of the } \\
\text { Estimate }\end{array}$ \\
\hline 1 & $.600^{\mathrm{a}}$ & .360 & .349 & 6.29872 \\
\hline
\end{tabular}

Sumber : Hasil olah data

Berdasarkan hasil estimasi model persamaan regresi yang telah dilakukan diatas diperoleh nilai koefisien determinasi R2 sebesar 0,360. Nilai ini berarti bahwa sebesar $36 \%$ variasi minat belajar siswa Kelas X Jurusan Ilmu Pengetahuan Sosial (IPS) Di SMA Negeri 1 Kota Gorontalo dipengaruhi oleh baik buruknya pemanfaatan teknologi informasi oleh siswa, sedangkan sisanya sebesar $64 \%$ dipengaruhi oleh variabel lain.

\section{KESIMPULAN}

Berdasarkan hasil penelitian dan pembahasan maka dapat dikemukakan kesimpulan penelitian sebagai berikut: Teknologi informasi berpengaruh positif dan signifikan terhadap minat belajar siswa Kelas X Jurusan Ilmu Pengetahuan Sosial (IPS) Di SMA Negeri 1 Kota Gorontalo. Besar pengaruh dari teknologi informasi terhadap minat belajar siswa mencapai 36\% sedangkan sisanya sebesar $64 \%$ dipengaruhi oleh variabel lain seperti pengelolaan kelas, ruang kelas yang nyaman, semangat siswa dalam belajar dan suasana kelas.

\section{DAFTAR PUSTAKA}

Arikunto, S. 2010. Prosedur Penelitian Suatu Pendekatan Praktik. Jakarta : Rineka Cipta. Sugiyono. 2006. Metode Penelitian Kuantitatif Kualitatif dan R\&D. Bandung: Alfabeta. Syaiful Bahri Djamarah dan Aswan Zain, Strategi Belajar Mengajar, Jakarta: Renika Cipta, 1995.

Slameto. (2003). Belajar dan faktor-faktor yang mempengaruhi. Jakarta: Rineka Cipta Slameto. 2010. Belajar dan Faktor- Faktor yang Mempengaruhinya. Jakarta: Rineka Cipta 
Syah, M. 2003. Psikologi Pendidikan dengan Pendekatan Baru. Bandung : Remaja Rosdakarya.

Rakhmansyah, Agil, M. Al Musadieq \& Heru Susilo. Pengaruh Penggunaan Teknologi Informasi Terhadap Kinerja (Studi pada Karyawan PT. PLN Area Madiun). 2014. Jurnal Administrasi Bisnis (JAB) Vol. 14 No. 1 Sepetember $2014: 1$ - 15.

Lucas, Henry J. 2000. Information Technology for Management, 7th ed. McGraw-Hill.

Widyawati, I., Sugiman, H. E. (2014). Pengaruh Penggunaan Gadget terhadap Daya Kembang Anak. Seminar Nasional Multidisiplin Ilmu, 10, 6-12

Benar, A. \&. (2019). Pengaruh Penggunaan Gadget Terhadap Hasil Belajar Siswa Pada Mata Pelajaran Ekonomi Siswa Kelas CI IPS DI SMA NEGERI 3 KOTA JAMBI. Journal of Chemical Information and Modeling, 53(9), 1689-1699. https://doi.org/10.1017/CBO9781107415324.004

Flora Siagian, R. E. (2015). Pengaruh Minat dan Kebiasaan Belajar Siswa terhadap Prestasi Belajar Matematika. Formatif: Jurnal Ilmiah Pendidikan MIPA, 2(2), 122-131. https://doi.org/10.30998/formatif.v2i2.93

Hariyani, T. (2014). Pengaruh Penggunaan Teknologi Informasi Dan Minat Pemanfaatan Teknologi Informasi Terhadap Kinerja Pegawai Di Bkkbn Kabupaten Madiun. Assets: Jurnal Akuntansi Dan Pendidikan, 3(2), 144. https://doi.org/10.25273/jap.v3i2.1219

Mulusi, \& Wardiyanto, M. (2013). Perbedaan kemandirian anak antara model pembelajaran berbasis area dengan model berbasis klasikal di usia taman kanakkanak. Jurnal Psikologi, 2(1), 56-61.

Purwanti, A. D. (2012). Penerapan Pendekatan Kontekstual untuk Meningkatkan Minat Belajar Siswa pada Pembelajaran IPA di Sekolah Dasar. Jurnal Ilmiah Guru, 16(2), 1-6.

Sunadi, L. (2010). Pengaruh Motivasi Belajar Dan Pemanfaatan Fasilitas Belajar Terhadap Prestasi Belajar Siswa Pada Mata Pelajaran Ekonomi Kelas Xi Ips Di SMA Muhammadiyah 2 Surabaya. Jurnal Pendidikan Ekonomi, 1-19. 